\title{
PROGRAM KEMITRAAN MASYARAKAT (PKM) BAGI MAHASISWA JURUSAN PENDIDIKAN GEOGRAFI FIS UNIMA
}

\author{
Selvana T.R. Tewal; Jelly Robot \\ Universitas Negeri Manado \\ selvanatewal@unima.ac.id \\ Abstrak
}

Permasalahn yang ditemukan sehingga dilaksanakan pengabdian ini adalah rendahnya pemahaman Mahasiswa Pendidikan Geografi yang telah mengikuti Mata Kuliah Evaluasi Pengajaran Geografi, khususnya dalam topik bahasan yang berkaitan dengan statistik, dan dalam hal ini khusus pendekatan Penilaian baik yang menyangkut penilaian Acuan Norma (PAN ) manupun Penilaian Acuan Patokan (PAP) serta latar belakang Pendidikan Mahasiswa Jurusan Pendidikan Geografi sewaktu di SMA umumnya berasal dari Jurusan IPS dan juga SMK.

Tujuan dilaksanakannya kegiatan Pengabdian ini adalah untuk meningkatkan pemahaman dan kompetensi Mahasiswa Jurusan Pendidikan Geografi dalam hal penerapan pendekatan penilaian dalam pembelajaran Geografi disaat melaksanakan kegiatan PPL 2 maupun setelah nanti berprofesi sebagai Guru Metode yang digunakan meliputi ceramah, tanya jawab, pemberian tugas/soal Latihan tentang penerapan pendekatan penilaian.

Hasil kegiatan berwujud produk materi pelatihan tentang penekatan penilaian dan hasil penyelesaian tugas soal Latihan penerapan pendekatan penilaian dalam pembelajaran

\section{Kata-Kata Kunci: Pelatihan, Pendekatan Penilaian, Mahasiswa}

\section{PENDAHULUAN}

\section{Analisis Situasi}

Penilaian dalam pembelajarn adalah suatu kegiatan yang mutlak harus dilakukan serta bertujuan untuk mendapatkan informasi tentang tercapainya tujuan pembelajaran secara khusus, bahkan dalam konteks yang lebih luas dalam rangka mendukung terwujudnya tujuan pendidikan secara Nasional.

Tercapainya tujuan pembelajaran dalam suatu proses pembelajaran selain ditentukan oleh komponen Guru, Siswa, materi, proses pembelajaran dan sarana pendukung, salah satu komponen yang tidak kalah pentingnya adalah alat penilaian yang digunakan dalam melaksanakan penilaian yakni tes maupun alat penilaian non tes. Menurut Suharsimi Arikunto (1997) Tes diartikan sebagai serentetan pertanyaan atau latihan atau alat lain yang digunakan untuk mengukur ketrampilan, pengetahuan, intelegensi, kemampuan atau bakat yang dimiliki individu atau kelompok. Mengacuh pada batasan yang telah dikemukakan, memberikan pemahaman bahwa melalui tes ataupun alat penilaian non tes informasi tentang kompetensi seseorang dapat 
Jurnal ABDIMAS, Vol. 13, No. 1, April 2020

ISSN: 1979-0953 | e-ISSN: 2598-6066

diperoleh sehingga untuk mendapatkan informasi yang tepat dibutuhkan tes sebagi alat ukur yang dapat memenuhi standar atau persyaratan suatu tes yakni Valid dan relabel, Ketepatan dan ketetapan suatu tes sebagai alat evaluasi, ditentukan oleh tepatnya rumusan butir-butir soal atau tepatnya konstruksi butir soal yang disusun untuk mendukung tujuan pembelajaran yang akan dicapai. Sehubungan dengan hal ini Asmawi dan Noehi (2005) mengemukakan bahwa suatu soal yang bermutu harus memiliki 3 karakteristik yakni tingkat kesukaran soal, daya pembeda dan berfungsi tidaknya pilihan atau distraktor/pengecoh.

Berkaitan dengan penilaian maka tentunya dibutuhkan penguasaan terhadap fungsi teknik dan pendekatan penilaian agar evaluator atau orang yang melakukan penilaian dapat mealukan penilaian dengan tepat. Menilai dengan tepat bagi seorang evaluator, ini erat kaitannya dengan penyusunan butir soal dan tingkat kesukaran soal, daya pembeda soal serta pendekatan penilaian yang mencakup pendekatan acuan patokan atau pendekatan acuan norma. Berdasarkan pengalaman dan pengamatan serta penilaian yang dilakukan selama beberapa tahun selama menjadi Pembina mata kuliah evaluasi pengajaran Geografi di Jurusan Pendidikan Geografi pada pokok bahasan yang berkaitan dengan perhitungan statistik umumnya Mahasiswa Jurusan Pendidikan Geografi mengalami kesulitan yang dibuktikan dengan rendahnya kemampuan menyelesaikan soal-soal latihan seperti Validitas dan reabilitas soal, tingkat kesukaran dan daya pembeda soal serta penerapan pendekatan penilaian disisi lain umumnya Mahasiswa Jurusan Pendidikan Geografi berlatar belakang Jurusan IPS di SMA dan juga dari SMK dan hanya sebagian kecil yang berlatar belakang Jurusan IPA. Berdasarkan uraian analisis situasi yang telah dikemukakan, maka Kegiatan Pengabdian pada Masyarakat dalam bentuk pelatihan tentang analisis butir soal dan penerapan pendekatan penilaian baik PAP maupun PAP bagi Mahasiswa Jurusan Pendidikan Geografi khususnya yang akan dipersiapkan mengikuti Program PPL 2 di Sekolah-Sekolah, sangat penting untuk dilakukan.

\section{Permasalahan Mitra}

Latar belakang Mahasiswa Jurusan Pendidikan Geografi yang umumnya berasal dari SMA dengan jurusan IPS dan juga dari SMK, sehingga kurang banyak bergelut dengan mata pelajaran yang didominasi dengan perhitungan-perhitungan matematis dan ini berdampak pada kemampuan menyelesaikan latihan-latihan yang berkaitan dengan perhitungan statistik saat mengikuti perkuliahan di Jurusan Geografi. Sementara 
Jurnal ABDIMAS, Vol. 13, No. 1, April 2020

ISSN: 1979-0953 | e-ISSN: 2598-6066

disisi lain khususnya mata kuliah evaluasi pembelajaran Geografi dengan bobot SKS 3 sebagai mata kuliah wajib bagi Mahasiswa Jurusan Pendidikan Geografi terdapat cukup banyak pokok bahasan yang harus melakuak perhitungan statistik seperti menghitung Validitas dan reliabilitas tes, Analisis Butir soal dan pengolahan nilai dengan pendekatan PAN dan PAP sehingga menuntut Mahasiswa mau tidak mau harus mengikutinya dan sesuai dengan pengalaman dan hasil penilaian selama beberapa tahun menjadi Pembina mata kuliah evaluasi pengajaran Geografi menunjukkan bahwa mahasiswa umumnya cukup mengalami kesulitan dalam menyelesaikan soal latihan yang diberikan yang tentunya berdampak pada hasil bealajar Mahasiswa secara keseluruhan dalam Mata Kuliah Evaluasi Pembelajaran Geografi. Berdasarkan uraian sebelumnya maka dirumuskan permasalahan sebagai berikut: Bagaimana meningkatkan kemampuan Mahasiswa Jurusan Pendidikan Geografi dalam melakukan analisis butur soal dan menilai dengan pendekatan PAN dan PAP

\section{SOLUSI DAN TARGET LUARAN}

Solusi dalam memecahkan masalah yang ditemukan dan dialami Mahasiswa Jurusan Penddidikan Geografi pada Proses Pembelajaran Evaluasi pengajaran Geografi khususnya dalam topik/ materi yang berkaitan dengan perhitungan statistik khususnya dalam topik Pendekatan penilaian acuan patokan (PAP) dan Penilaian Acuan Norma (PAN) adalah sebagai berikut:

1. Menyiapkan materi Pendekatan penilaian baik acuan Norma maupun penilaian acuan patokan bagi Mahasiswa

2. Memberikan penjelasan materi diikuti dengan kegiatan pelatihan

3. Memberikan contoh cara mengaplikasikan rumus perhitungan Penilaian Acuan Norma dan Penilaian Acuan Patokan

4. Memberikan penugasan dan pendampingan serta bimbingan dalam menerapkan pendekatan penilaian dalam pembelajaran Geografi.

Luaran yang dihasilkan dalam kegiatan pelatihan bagi Mahasiswa Jurusan Pendidikan Geografi tentang topik pendekatan penilaian, berwujud:

1. Materi Pendekatan Penilaian baik Penilaian Acuan Patokan maupun Penilaian Acuan Norma

2. Hasil kerja berwujud penyelesaian soal Latihan tentang penerapan pendekatan penilaian dalam pembelajaran

3. Artikel Ilmiah 
Jurnal ABDIMAS, Vol. 13, No. 1, April 2020

ISSN: 1979-0953 | e-ISSN: 2598-6066

\section{METODE PELAKSANAAN}

Metode yang digunakan dan ditempuh dalam kegiatan pengabdian ini sebagai berikut:

1. Membagikan materi pendekatan penilaian yang telah disusun/disiapkan

2. Menjelaskan tentang pendekatan penilaian dalam pembelajaran geografi

3. Melaksanakan kegiatan pelatihan dan pembimbingan

4. Memberikan contoh aplikasi pendekatan penlaian

5. Memberikan tugas/soal Latihan

Metode ini dapat menjawab permasalah yang dihadapi Mahasiswa dan juga Dosen Mata Kuliah Evaluasi Pengajran Geografi karena rendahnya pemahaman Mahasiswa pada materi Evaluasi pengajaran Geografi yang berkaitan dengan statistic dapat ditingkatkan .

\section{KELAYAKAN PERGURUAN TINGGI}

Untuk menjawab permasalahan dan kebutuhan peserta pelatihan dapat terpenuhi karena di Jurusan Pendidikan Geografi terdapat Tim Mata Kuliah Evaluasi Pembelajaran Geografi .dimana Mata Kuliah Evaluasi Pembelajaran Geografi adalah salah satu mata kuliah yang sangat menopang bagi penyiapan guru yang professional khususnya dalam kompetensi atau kemampuan melakukan penilaian hasil dan proses pembelajaran.

\section{HASIL DAN LUARAN YANG DICAPAI}

Hasil dan luaran yang dicapai daalam kegiatan pengabdian ini berwujud hasil perhitungan tentang penerapan penilaian yang dikerjakan oleh Mahasiswa peserta kegiatan pelatihan. Mahasiswa peserta pelatihan mampu mengikuti kegiatan dengan baik yang ditunjukkan oleh hasil penyelesain soal/tugas tentang penerapan pendekatan penilaian.

\section{KESIMPULAN DAN SARAN}

\section{Kesimpulan}

Pelatihan tentang penerapan pendekatan penilaian bagi Mahasiswa Jurusan Pendidikan Geografi penting dilakukan guna penyegaran dan peningkatan pemahaman dan kompetensi Mahasiswa dalam melaksanakan penilaian serta menerapkan pendekatan penilaian baik pendekatan acuan patokan (PAP) maupun pendekatan penilaian acuan norma (PAN).

\section{Saran}

Kegiatan pelatihan seperti ini dapat dilakukan juga untuk mata kuliah lain yang berkaitan dengan penerapan rumus statistic atau juga dalam mata kuliah yang sama dengan Angkatan yang berbeda dengan karakteristik Mahsiswa yan sama dalam hal ini latar 
belakang Jurusan mereka sewaktu di SMA/SMK.

\section{DAFTAR PUSTAKA}

[1] Asmawi Zainal, Noehi Nasution, 2005, Penilaian Hasil Belajar, Pusat Antar Universitas Untuk Peningkatan dan Pengembangan Aktivitas Instruksional, Direktorat Jenderal Pendidikan Tinggi, Departemen Pendidikan Nasional, Jakarta

[2] Awan Mutakin,Mamat Ruhimat, Ahmad Yani, 1998, Penilaian Dalam Pendidikan, Mitra Siswa, Bandung

[3] James Phopam, 1981, Modern Educational Measurement.Prentice Hall, Wellington New Zealand

[4] Suharsimi Arikunto, 1997. Dasar Dasar Evaluasi Pendidikan. Bumi Aksara Jakarta

[5] Suharsimi Arikunto, 1987, dasar-dasar Evaluasi Pendidikan, Bina Aksara, Jakarta

[6] Suryatna Rafi,I 1990, Teknik Evaluasi, Angkasa Bandung 